\title{
Profil Kesadaran Metakognisi Siswa di salah satu SMA Swasta di Sragen
}

\author{
Husna Ainun Fauziah, Astin Putri Setyowati, Rinika Dewantari, Adesty Dwi \\ Wulandari, Baskoro Adi Prayitno \\ Pendidikan Biologi, Fakultas Keguruan dan Ilmu Pendidikan, Universitas Sebelas \\ Maret \\ Jl. Ir. Sutami No.36A, Jebres, Kota Surakarta, Jawa Tengah 57126 \\ e-mail: husnaainunfauziah@ @student.uns.ac.id
}

\begin{abstract}
Abstrak
Penelitian ini bertujuan mengetahui profil kesadaran metakognisi siswa di salah satu SMA swasta di Sragen. Penelitian ini menggunakan metode survei. Populasi penelitian adalah seluruh siswa kelas X MIA dan XI MIA yang berjumlah 240 siswa. Teknik sampling menggunakan stratified propotional random sampling dengan jumlah sampel sebanyak 30 siswa yang diambil dari kelas X dan XI MIA. Kesadaran metakognisi diukur menggunakan MAI (Metacognitive Awareness Inventory) yang dikembangkan oleh Schraw dan Dennison (1994). Indikator kesadaran metakognisi yang diukur meliputi pengetahuan tentang kognisi (knowledge about cognition) terdiri dari subindikator pengetahuan deklaratif, pengetahuan prosedural, pengetahuan kondisional dan indikator regulasi kognisi (regulation of cognition) terdiri dari subindikator perencanaan, strategi manajemen informasi, monitoring pemahaman, strategi prediksi dan evaluasi. Analisis data menggunakan analisis deskriptif kuantitatif. Hasil penelitian menunjukkan kesadaran metakognisi siswa secara umum sebesar 73,94\% (baik). Indikator pengetahuan tentang kognisi siswa dalam kategori baik dengan persentase sebesar 62,99\% dengan subindikator pengetahuan deklaratif 76,25\% (baik), pengetahuan prosedural 74,79\% (baik), pengetahuan kondisional 37,92\% (kurang). Indikator pengetahuan tentang regulasi kognisi dalam kategori baik dengan persentase sebesar $73,51 \%$ dengan subindikator perencanaan $69,64 \%$ (baik), strategi manajemen informasi 71,42\% (baik), monitoring pemahaman $75,24 \%$ (baik), strategi prediksi 79,33\% (baik), dan evaluasi 71,94\% (baik).
\end{abstract}

Kata Kunci-kesadaran metakognisi, pengetahuan metakognisi, regulasi kognisi, Metacognitive Awareness Inventorv

\begin{abstract}
Abstrak
The purpose of research is to determine the profil of metacognition awareness in one of Private High School in Sragen. The research uses survey method with population is all students of class X MIA and XI MIA which amounted to 240 students. The technique of sampling used stratified propotional random sampling with the number of samples 30 students who have been taken from the class X and XI MIA. Metacognition awareness was measured using MAI (Metacognitive Awareness Inventory) developed by Schraw and Dennison (1994). Metacognition awareness indicators measured include knowledge about cognition consist of declarative knowledge sub-indicators, procedural knowledge, conditional knowledge and regulatory cognition indicators consist of planning subindicators, information management strategies, understanding monitoring, prediction and evaluation strategies. Data analysis using quantitative descriptive. The result showed that students' metacognition awareness in general was $73,94 \%$ (good). Indicator knowledge about cognition of students in good category with percentage equal to 62,99\% with sub-indicator of declarative knowledge 76,25\% (good), knowledge of procedural 74,79\% (good), conditional knowledge $37,92 \%$ (less). Indicator knowledge of cognition regulation in good category with percentage of $73,51 \%$ with sub-indicator of planning 69,64\% (good), information management strategy $71,42 \%$ (good), monitoring understanding 75,24\% (good), prediction strategy 79,33\% (good), and evaluation 71,94\% (good).
\end{abstract}

Keywords - metacognition awareness, metacognition knowledge, cognition practice, metacognitive awareness inventory 


\section{PENDAHULUAN}

Perkembangan pendidikan abad 21 semakin lama semakin berkembang karena dunia pendidikan bersifat dinamis. Pada era globalisasi, ilmu pengetahuan dan teknologi semakin maju, kesadaran terhadap hak dan kewajiban asasi manusia, kerjasama dan kompetisi antar bangsa menuntut setiap manusia meningkatkan kualitas pendidikan (Efendi, 2013). Keberhasilan pendidikan suatu bangsa merupakan salah satu barometer keberhasilan pemerintahan suatu negara. Hal ini dapat dimulai dari pondasi pendidikan yang kokoh untuk mewujudkan citacita mulia suatu bangsa dalam berbagai sektor dan aspek kehidupan termasuk kedisiplinan, etos kerja, nilai, dan moral suatu bangsa. Keberhasilan pendidikan merupakan landasan bagi perkembangan ekonomi dan sosial masyarakat. Pendidikan adalah kata kunci dalam mengembangkan pengetahuan dan kualitas kemampuan masyarakat. Ini artinya pendidikan merupakan kunci utama dalam meningkatkan kualitas suatu bangsa. Oleh karena itu, perlu adanya pembenahan dan perbaikan kualitas pendidikan dari waktu ke waktu, salah satunya dengan meningkatkan kesadaran metakognisi.

Dewasa ini pemerintah banyak melakukan upaya perbaikan, salah satunya melalui Kurikulum 2013 yang menitikberatkan pada penguasaan aspek pengetahuan, aspek keterampilan, dan aspek sikap oleh siswa dengan pengetahuan yang faktual, konseptual, prosedural, dan metakognisi dalam ilmu pengetahuan, teknologi, seni, dan budaya. Metakognisi merupakan salah satu Standar Kompetensi Lulusan (SKL) dari aspek pengetahuan yang harus dikuasai oleh siswa SMA dalam Kurikulum 2013. Hal tersebut menunjukkan bahwa metakognisi harus dicapai dan penting untuk dimiliki oleh siswa SMA maupun SMK dalam Kurikulum 2013.

Dengan demikian, kesadaran metakognisi sangat penting dimiliki oleh setiap siswa untuk melahirkan kesadaran dalam proses berpikir dan mengevaluasi diri terhadap hasil proses berpikir serta pengalamannya. Siswa dengan penguasaan kesadaran metakognisi akan memperkecil kesalahan yang dibuat dalam menyelesaikan masalah dan dapat membantu dalam mengidentifikasi strategi belajar dengan baik.

Kesadaran metakognisi adalah kesadaran individu dalam menggunakan pemikirannya untuk merencanakan, mengontrol, dan menilai terhadap proses dan strategi kognitif. Siswa dikatakan dapat menguasai kesadaran metakognisi apabila siswa telah memenuhi indikator merencanakan, memantau, dan mengevaluasi kognisinya (Lie dalam Prayitno, 2017). Siswa sekolah menengah dianjurkan memiliki kesadaran metakognisi karena erat kaitannya dengan cara berpikir yang dapat mengoptimalkan keterampilan otak dalam kesadaran berpikir, mengetahui akibat yang ditimbulkan, dan kesadaran diri yang sudah seharusnya dimiliki siswa sekolah menengah (Hill, 2001). Kesadaran metakognisi yang harus dikuasai siswa menurut Schraw dan Dennison (1994), terdiri atas dua komponen utama, yaitu pengetahuan metakognisi dan regulasi metakognisi. Pengetahuan metakognisi mengacu pada pengetahuan tentang kognisi seperti pengetahuan tentang keterampilan (skill) dan strategi kerja yang baik untuk peserta didik dan bagaimana serta kapan menggunakan keterampilan dan strategi tersebut. Regulasi metakognisi mengacu pada kegiatan-kegiatan yang mengontrol pemikiran dan belajar seseorang, seperti merencanakan, memonitor pemahaman, dan evaluasi (Danial, 2010). Kesadaran metakognisi membantu siswa untuk merencanakan, mengurutkan, dan memantau proses pembelajaran mereka agar hasil belajar yang diperoleh lebih baik (Adhitama, Kusnadi, \& Supriatno, 2014).

Kenyataan yang ada, tidak semua siswa dapat menggunakan kesadaran metakognisinya dengan baik dalam memecahkan masalah. Salah satu penelitian menunjukkan bahwa antara siswa yang memecahkan suatu masalah dengan benar dan siswa yang melakukan kesalahan dalam memecahkan masalah mempunyai kesadaran metakognisi yang berbeda (Alfiyah \& Siswono, 2014). Penelitian lain menunjukkan bahwa masih banyak siswa yang mengalami kesulitan dalam menggunakan kesadaran metakognisi, ketika dihadapkan pada masalah (Bulu, 2015). Hasil penelitian yang ada mengindikasikan bahwa tidak semua siswa mampu menggunakan kesadaran 
metakognisi dengan baik dan masih mengalami kesulitan metakognisi dalam memecahkan masalah.

Kesadaran mengenai penguasaan metakognisi di Indonesia masih dalam kriteria rendah. Siswa masih belum menguasai dan belum mampu menerapkan kesadaran metakognisi dalam kegiatan sehari-hari, khususnya dalam kegiatan belajar. Keterampilan mengenai penguasaan kesadaran metakognisi yang rendah didukung oleh hasil studi internasional yang menunjukkan bahwa keterampilan anak Indonesia usia 15 tahun di bidang matematika, sains dan membaca masih rendah di bandingkan dengan anak-anak lain di dunia. Hasil survei Programme for International Student Assessment (PISA) 2007, menempatkan Indonesia pada peringkat ke-64 dari 65 negara yang berpartisipasi dalam tes. Hasil survei internasional Trends in International Mathematics and Science Study (TIMSS) 2011 juga masih rendah, Indonesia menduduki peringkat ke-38 dari 42 negara, skor Indonesia berada di bawah rata-rata skor internasional. Fakta yang ada mengindikasikan suatu masalah yang harus dipecahkan dari proses pendidikan di Indonesia (Fitria, Sujadi, \& Subanti, 2016).

Berdasarkan uraian di atas, diketahui bahwa penguasaan kesadaran metakognisi merupakan suatu hal yang penting dan memiliki manfaat yang besar dalam membantu siswa memecahkan masalah dalam kehidupan sehari-hari. Penelitian mengenai kesadaran metakognisi siswa belum pernah dilakukan di Sragen sebelumnya yang merupakan salah satu kabupaten di Provinsi Jawa Tengah, dengan demikian penulis melakukan penelitian dengan judul "Profil Kesadaran Metakognisi Siswa di salah satu SMA Swasta di Sragen" yang bertujuan untuk mengetahui profil kesadaran metakognisi siswa di salah satu SMA Swasta di Sragen.

\section{METODE PENELITIAN}

Metode yang digunakan dalam penelitian adalah metode survei. Populasi penelitian adalah seluruh siswa kelas X dan XI MIA di salah satu SMA swasta di Sragen yang berjumlah 240 siswa. Teknik sampling menggunakan stratified propotional random sampling dengan jumlah sampel sebanyak 30 siswa. Prosedur pengambilan sampel sebagai berikut: (1)
Menetapkan sebanyak 10\% sampel dari populasi. (2) Mengambil sampel sejumlah 15 siswa dari tiap jenjang kelas X dan XI. (3) Memilih secara acak sampel sejumlah 3 sampai 4 siswa dari kelas MIA 1 - MIA 4 pada masing-masing jenjang.

Kesadaran metakognisi diukur menggunakan MAI (Metacognitive Awareness Inventory) yang dimodifikasi dari Schraw dan Dennison (1994) dikutip dari (Arahma, 2017) yang telah teruji validitas dan reliabilitasnya. Indikator kesadaran metakognisi yang diukur meliputi pengetahuan tentang kognisi (knowledge about cognition) terdiri dari subindikator pengetahuan deklaratif, pengetahuan prosedural, pengetahuan kondisional dan indikator regulasi kognisi (regulation of cognition) terdiri dari subindikator perencanaan, strategi manajemen informasi, monitoring pemahaman, strategi prediksi dan evaluasi.

Pengambilan data menggunakan MAI dilakukan dengan mengumpulkan sampel siswa dalam dua ruang kelas terpisah dengan jumlah masing-masing 15 siswa dengan waktu pengerjaan angket selama 20 menit. MAI (Metacognitive Awareness Inventory) berisi 52 butir pernyataan positif yang mewakili masingmasing indikator dan subindikator. MAI menggunakan skala Likert bertujuan untuk mengumpulkan informasi mengenai kesadaran metakognisi siswa. Skala Likert menyajikan pilihan dengan skala 1 untuk kategori Sangat Tidak Benar (STB), skala 2 untuk kategori Tidak Benar (TB), skala 3 untuk kategori Benar (B), dan skala 4 untuk kategori Sangat Benar (SB) dengan menghilangkan poin netral.

Data yang diperoleh dianalisis menggunakan analisis deskriptif kuantitatif. Analisis data dilakukan dengan mengolah data menjadi persentase dan dikategorisasikan. Kategorisasi bertujuan untuk mengumpulkan informasi mengenai kesadaran metakognisi siswa. Berikut rentang kategorisasi yang digunakan dapat dilihat pada tabel 1 .

Tabel 1.

Kategorisasi Kesadaran Metakognisi

\begin{tabular}{cc}
\hline \hline Rentang Nilai (\%) & Katogorisasi \\
\hline $0-19.99$ & Kurang Sekali \\
\hline $20-39.99$ & Kurang \\
\hline \hline
\end{tabular}




\begin{tabular}{cc}
\hline \hline $40-59.99$ & Cukup \\
\hline $60-79.99$ & Baik \\
\hline $80-100$ & Baik Sekali \\
\hline \hline
\end{tabular}

\section{HASIL DAN PEMBAHASAN}

\section{A. Profil Kesadaran Metakognisi}

Kesadaran metakognisi merupakan kesadaran individu dalam menggunakan pemikirannya untuk merencanakan, mengontrol, dan menilai terhadap proses dan strategi kognitif. Tabel 2 menyajikan rata-rata kesadaran metakognisi siswa yang memiliki rata-rata sebesar $73,94 \%$ termasuk dalam kategori baik. Hal ini didukung dengan data kesadaran metakognitisi siswa yang diperoleh.

Tabel 2.

Kesadaran Metakognisi

\begin{tabular}{lcc|}
\hline \hline \multicolumn{1}{c}{ Indikator } & $\begin{array}{c}\text { Rata-rata } \\
(\%)\end{array}$ & Kategori \\
\hline Pengetahuan Deklaratif & 76,25 & Baik \\
Pengetahuan prosedural & 74,79 & Baik \\
Pengetahuan kondisional & 37,92 & Kurang \\
Perencanaan (planning) & 69,64 & Baik \\
Strategi manajemen informasi & 71,42 & Baik \\
Monitoring pemahaman & 75,24 & Baik \\
Strategi prediksi & 79,33 & Baik \\
Evaluasi & 71,94 & Baik \\
\hline \hline \multicolumn{1}{c}{ Rata-rata Keseluruhan } \\
\hline Kesadaran Metakognisi & 73,94 \\
\hline \hline
\end{tabular}

Kesadaran metakognisi merupakan potensi yang dimiliki siswa (Herlanti, 2015). Secara garis besar, rata-rata kesadaran metakognitf siswa baik. Data hasil penelitian menunjukkan hanya terdapat tiga kategori tingkat kesadaran metakognisi yang muncul, yaitu sangat baik, baik, dan cukup. Berdasarkan data analisa data pada gambar 1,20\% masuk kategori baik sekali, $77 \%$ siswa memiliki tingkat kesadaran yang tergolong baik, dan 3\% ketegori cukup.

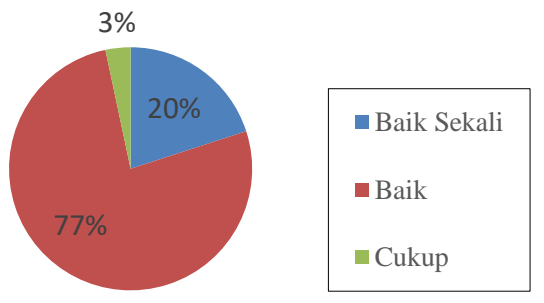

Gambar. 1. Persentase Tingkat Kesadaran Metakognisi siswa

Kesadaran metakognisi memiliki indikatorindikator tingkat yang terhubungan satu sama lain. Pengetahuan deklaratif memiliki keterkaitan dengan pengetahuan prosedural, dimana ketika seseorang menyadari bahwa ia ia tidak memahami sesuatu, lalu ia memiliki strategi untuk mencari informasi yang ia butuhkan, maka strategi itulah yang merupakan bagian dari pengetahuan prosedural. Jadi, dalam hal ini, pengetahuan prosedural dapat bertindak sebagai pelaksana atau penerapan dari pengetahuan deklaratif seseorang.

Hubungan pengetahuan prosedural dan pengetahuan kondisional sangat erat karena keduanya terkait dengan strategi belajar yang digunakan oleh siswa. Ketika seorang siswa memahami strategi-strategi belajar yang diperlukannya dengan baik, maka sudah seharusnya ia memahami pula kapan dan mengapa strategi tersebut digunakan. Sebaliknya,ketika siswa telah dapat menggunakan suatu strategi belajar dalam situasi tertentu, artinya ia juga telah memiliki pengetahuan tentang bagaimana menggunakan strategi belajar yang baik (Adhitama et al., 2014).

\section{B. Profil Indikator Pengetahuan tentang Kognisi (knowledge about cognition)}

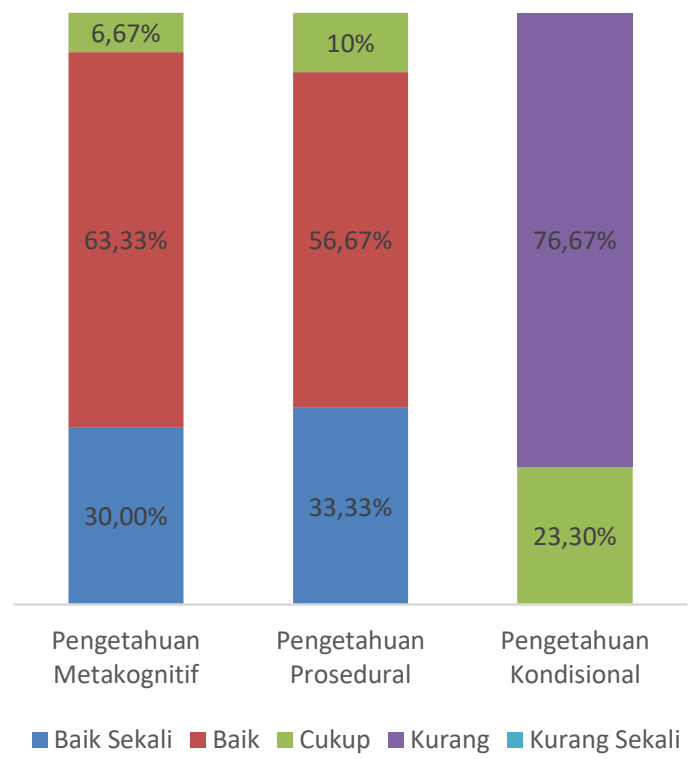


Gambar 2. Persentase Profil Tingkat Kesadaran Pengetahuan tentang Kognisi

\section{1) Subindikator Pengetahuan Deklaratif}

Pengetahuan deklaratif merupakan pengetahuan tentang sesuatu. Pengetahuan deklaratif meliputi pengetahuan tentang diri sendiri sebagai pelajar dan tentang faktor-faktor yang mempengaruhi pengetahuan seseorang. Berdasarakan tabel 2 kesadaran pengetahuan deklaratif siswa memiliki rata-rata sebesar 76,25\%. Hasil ini menunjukkan bahwa pengetahuan deklaratif berada dalam kategori baik.

Berdasarkan gambar 2 subindikator pengetahuan deklaratif memiliki variasi persentase kesadaran, sebanyak $63,33 \%$ menunjukkan hasil yang baik, $6,67 \%$ menunjukkan hasil cukup dan sebanyak $30 \%$ menunjukkan hasil baik sekali. Terlihat dari hasil persentase kesadaran pengetahuan deklaratif lebih dari 50\% menunjukkan hasil yang baik. Hal ini mendukung rata-rata yang diperoleh bahwa pengetahuan deklaratif siswa dikategorikan baik.

Pengetahuan deklaratif siswa di sekolah tersebut baik, karena model pembelajaran yang diterapkan di sekolah tersebut tepat dan dilaksanakan dengan baik. Lingkungan sekolah juga mendukung untuk pengembangkan pengetahuan deklaratif siswa menjadi baik. Model pembelajaran yang ditetapkan di sekolah tersebut adalah model pembelajaran discovery learning. Model pembelajaran discovery learning menuntut siswa untuk aktif. Untuk menunjang proses pembelajaran perlu adanya lingkungan yang memfasilitasi rasa ingin tahu siswa terhadap eksplorasi.

\section{2) Subindikator Pengetahuan Prosedural}

Pengetahuan prosedural merupakan kesadaran proses berpikir atau pengetahuan cara-cara untuk mencapai tujuan dan pengetahuan bagaimana terampil bekerja dan bagaimana melakukannya. Seseorang yang mempunyai pengetahuan prosedural tingkat tinggi dapat menggunakan strategi yang berbeda-beda untuk memecahkan permasalahan yang dihadapi.

Berdasarkan tabel 2 kesadaran pengetahuan prosedural siswa memiliki rata-rata sebesar 74,79\%. Hasil ini menunjukkan bahwa kesadaran pengetahuan tentang kognisi berada dalam kategori baik.
Berdasarkan gambar 2 subindikator pengetahuan prosedural memiliki variasi persentase, sebanyak 56,67\% menunjukkan hasil baik, 33,33\% menujukkan hasil sangat baik dan $10 \%$ menunjukkan hasil cukup. Lebih dari 50\% menunjukkan hasil yang baik terhadap pengetahuan prosedural. Hal ini mendukung ratarata yang diperoleh bahwa kesadaran prosedural dari para siswa dikategorikan baik.

Pengetahuan prosedural yang baik ini didukung oleh beberapa faktor yang cukup signifikan antara lain seperti rendahnya tingkat kejenuhan siswa dalam belajar. Rendahnya tingkat kejenuhan siswa dalam belajar dapat dikarenakan gaya pembelajaran yang dilakukan oleh guru dapat menarik perhatian siswa sehingga pembelajaran dikelas menjadi tidak membosankan bagi siswa.

\section{3) Subindikator Pengetahuan Kondisional}

Pengetahuan kondisional merupakan pengetahuan yang menggambarkan mengenai kapan dan mengapa siswa memilih suatu strategi tertentu untuk memecahkan masalah (Nurmalasari, Winarso, \& Nurhayati, 2015). Pengetahuan kondisional mengacu pada pengetahuan mengenai situasi-situasi dimana siswa dapat menggunakan pengetahuan metakognisi (Suwarto, 2010). Pengetahuan kondisional berperan terhadap pengambilan keputusan siswa tentang kapan suatu prosedur atau strategi digunakan dan kapan tidak digunakan, pada kondisi seperti apa suatu strategi yang dipilih dapat digunakan, serta mengapa suatu strategi lebih dipilih dibandingkan dengan strategi lain (Pathuddin, 2009).

Berdasarkan tabel 2 rerata kesadaran pengetahuan kondisional siswa adalah $38 \%$. Gambar 2 menunjukkan bahwa terdapat variasi persentase pada tingkat kesadaran indikator pengetahuan kondisional yaitu $76,67 \%$ dengan kategori kurang dan 23,30\% dengan kategori cukup. Setiap siswa memiliki situasi dan kondisi yang berbeda sehingga dibutuhkan kesadaran untuk mampu menempatkan strategi belajarnya.

Rata-rata kesadaran pengetahuan kondisional siswa adalah 38\% dan masuk dalam kategori kurang. Faktor dari hasil pengetahuan kondisional yang kurang diakibatkan oleh banyaknya siswa tidak mengetahui kapan suatu 
strategi yang efektif digunakan untuk memecahkan suatu masalah. Kurangnya kesadaran pengetahuan kondisional di salah satu SMA Sragen ini disebabkan karena pembelajaran di sekolah belum mendorong aktivitas siswa untuk mengembangkan kemampuan kondisional serta kurangnya peran guru dalam menekankan pemahaman siswa terhadap penguasaan konsep dari materi. Pemahaman konseptual merupakan kemampuan untuk menentukan konsep mana yang relevan dan tepat digunakan dalam menyelesaikan permasalahan pada kondisi tertentu. Menurut Lukum, Laliyo, \& Sukamto, (2015) baik maupun kurangnya kesadaran pengetahuan kondisional siswa pada dasarnya berhubungan dengan pemahaman konseptual.

\section{Indikator Regulasi Kognisi (regulation of cognition)}

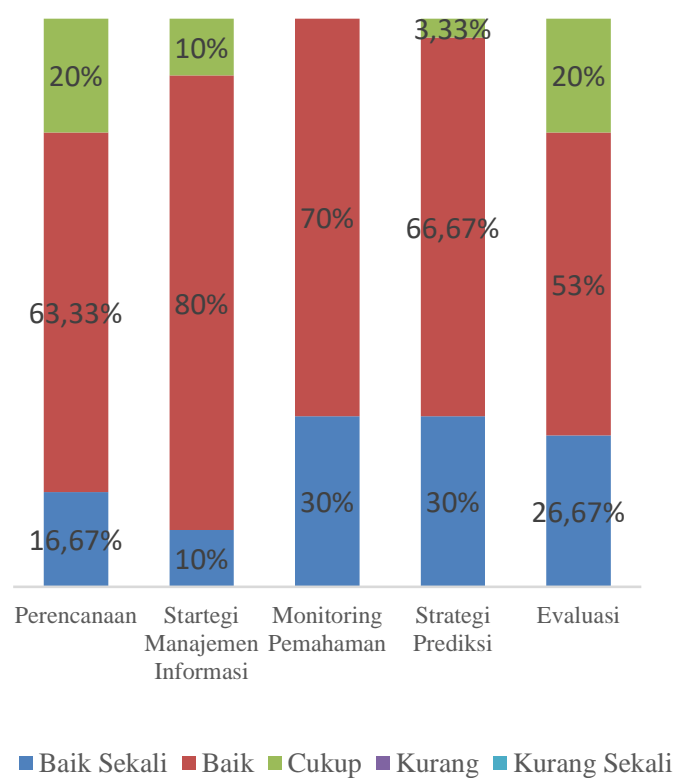

Gambar 3. Persentase Tingkat Kesadaran Regulasi Kognisi

\section{1) Subindikator Perencanaan}

Perencanaan (planning) merupakan proses merancang sebuah solusi yang sesuai dengan kriteria permasalahan yang sedang dihadapi. Proses perencanaan mengembangkan sebuah rencana untuk menyelesaikan sebuah masalah. Proses merencanakan berhenti pada tahap pelaksanaan langkah-langkah untuk menciptakan solusi nyata yang dapat diterapkan pada suatu masalah (Suwarto, 2010). Perencanaan meliputi menetapkan tujuan, membuat estimasi waktu yang relevan, dan memilih strategi yang tepat dan efektif (Iskandar, 2014).

Berdasarkan tabel 2 rerata kesadaran perencanaan siswa adalah 69,64\%. Gambar 3 menunjukkan bahwa terdapat variasi persentase pada tingkat kesadaran indikator perencanaan yaitu 16,67\% dalam kategori baik sekali, 63,33\% siswa dalam kategori baik dan $20 \%$ berada pada kategori cukup. Perbedaan kategori tersebut disebabkan karena setiap siswa memiliki pengalaman metakognisi berbeda.

Rata-rata kesadaran pengetahuan perencanaan siswa adalah 69,64\% dan masuk dalam kategori baik. Faktor yang menyebabkan kesadaran pengetahuan perencanaan masuk dalam kategori baik, karena penerapan model discovery learning di sekolah ini yang menyebabkan siswa banyak menemukan suatu hal baru secara mandiri, sehingga mendorong siswa melakukan suatu perencanaan untuk menemukan hal baru maupun dalam menyelesaikan suatu permasalahan. Tahap perencanaan penting dilakukan karena mengarah pada rancangan sebuah solusi yang sesuai dan melibatkan indikator perencanaan tujuan belajar, perencanaan penggunaan waktu menyelesaikan tugas, serta perencanaan penggunaan strategi yang efektif (Hidayat, 2013).

\section{2) Subindikator Strategi Manajemen Informasi}

Strategi manajemen informasi menurut Anderson \& Krathwohl merupakan kemampuan mengelola informasi sebagai rangkaian kemampuan dan strategi yang digunakan untuk memproses informasi secara lebih efisien, mencakup mengorganisir, menguraikan, merangkum, dan memfokuskan informasi yang penting (Adhitama et al., 2014). Strategi manajemen informasi yang merupakan bagian regulasi kognisi berperan terhadap aktivitas langsung yang terjadi selama siswa belajar (Maswandi, 2015). Berdasarkan tabel 2 kesadaran strategi manajemen informasi siswa dengan rerata $71,42 \%$ masuk dalam kategori baik. Rata-rata strategi manajemen informasi manajemen tersebut menunjukkan siswa mampu memproses informasi secara efisien. 
Berdasarkan gambar 3 terlihat bahwa subindikator strategi manajemen informasi memiliki persentase yang tinggi pada tingkat kesadaran kategori baik sebanyak $80 \%$. Tingkat kesadaran subindikator strategi manajemen informasi memiliki variasi pada rentang kategori baik sekali $10 \%$, baik $80 \%$, dan cukup $10 \%$. Hal ini mendukung data dari kemampuan regulasi yang menunjukkan rata-rata yang baik. Kesadaran strategi manajemen yang baik akan ikut membantu strategi pengetahuan metakognisi untuk mencapai tujuan kognisi (Maswandi, 2015). Strategi manejemen informasi yang baik didukung oleh kesadaran perencanaan yang baik pula. Strategi manajemen informasi dapat dilatihkan melalaui model kegiatan pembelajaran, salah satunya menggunakan discovery learning yang digunakan di sekolah ini. Model pembelajaran ini mendorong siswa aktif mengelola informasi yang didapatkan untuk membantunya menyelesaikan masalah.

\section{3) Subindikator Monitoring Pemahaman}

Monitoring pemahaman digunakan untuk memantau sejauh mana siswa mengetahui apa yang belum dikuasainya (Adhitama et al., 2014). Berdasarkan tabel 2 kesadaran monitoring pemahaman siswa memiliki rerata $75,24 \%$ yang masuk dalam kategori baik. Hal ini menunjukkan siswa mampu memahami dan mengelola materi pelajaran yang diperoleh (Maswandi, 2015).

Berdasarkan gambar 3 terlihat bahwa subindikator monitoring pemahaman memiliki tingkat kesadaran dengan persentase cenderung berbeda dari indikator lain pada regulasi metakognisi. Monitoring pemahaman hanya memiliki persentase pada rentang kategori baik sekali $30 \%$ dan baik $70 \%$. Hal ini menujukkan hasil yang positif artinya keseluruhan siswa sudah mampu memonitoring pemahaman yang dimilikinya secara mandiri.

Strategi monitoring pemahaman yang baik dapat dilatihkan melalaui model kegiatan pembelajaran, salah satunya menggunakan discovery learning yang digunakan di sekolah ini. Model pembelajaran ini melatih siswa secara mandiri untuk mengkonfirmasi ulang pemahamannya melalui pembukian hipotesis, sehingga siswa mampu memonitoring pemahamannya sendiri.

\section{4) Subindikator Strategi Prediksi}

Strategi prediksi yang dimaksud merupakan strategi prediksi untuk memperbaiki kesalahan (Adhitama et al., 2014). Berdasarkan tabel 2 kesadaran strategi prediksi pemahaman siswa memiliki rerata $79,33 \%$ yang masuk dalam kategori baik. Rata-rata menujukkan siswa sudah baik dalam mengatasi masalah- masalah yang dia temui selama belajar.

Berdasarkan gambar 3 terlihat bahwa subindikator strategi prediksi memiliki persentase yang tinggi pada tingkat kesadaran kategori baik sebanyak $66,67 \%$. Tingkat kesadaran subindikator strategi strategi prediksi memiliki variasi pada rentang baik sekali $30 \%$, baik 66,67\%, dan cukup 3,33\%. Artinya keseluruhan siwa secara berimbang sudah mampu melalukan strategi prediksi untuk mengatasi masalah ketika mengalami kesulitan saat belajar.

Strategi prediksi dapat dilatihkan melalaui model kegiatan pembelajaran, salah satunya menggunakan discovery learning yang digunakan di sekolah ini. Siswa setelah mengetahui apa yang belum dikuasainya melalui monitoring pemahaman yang dilatih dengan model pembelajaran. Selanjutnya siswa diharapkan dapat menyusun strategi prediksi untuk memperbaikinya (Adhitama et al., 2014).

\section{5) Subindikator Evaluasi}

Pada subindikator evaluasi, subindikator ini sejalan dengan tahap terakhir pada pembelajaran berbasis proyek, yaitu Evaluate the Experience. Pada akhir proses pembelajaran, guru dan siswa melakukan refleksi terhadap aktivitas dan hasil proyek yang sudah dilakukan. Siswa dapat melakukan evaluasi dengan bertanya kepada dirinya sendiri, sebaik apa ia dalam memahami suatu topik atau dalam mengerjakan proyek yang ditugaskan (Adhitama et al., 2014).

Berdasarkan analisa data pada gambar 3, evaluasi terdapat 3 kategori, yaitu cukup dengan rerata $20 \%$, baik $53 \%$, dan baik sekali dengan rerata 26,67\%. Hasil ini masuk dalam kategori baik karena rata-ratanya mencapai $71,94 \%$ sehingga hal ini dapat dikatakan bahwa kesadaran siswa dalam mengevaluasi diri dalam proses pembelajaran sudah tercapai. 
Pengembangan perencanaaan strategi dan kegiatan belajar sangat dipengaruhi oleh kesadaran metakognisi, pengetahuan tentang strategi belajar, dan pemahaman mengenai konteks tempat dia akan belajar. Semakin efektif siswa dalam mengembangkan perencanaan strategi pengelolaan diri (personal), perilaku, dan lingkungannya maka semakin tinggi tingkat regulasi diri (self regulation) siswa tersebut (Schunk \& Zimmerman, 2007). Proses self regulation dilakukan agar seseorang atau individu dapat mencapai tujuan yang diharapkannya. Hal inilah yang menjadi faktor penyebab siswa dapat mencapai kategori baik dalam mengevaluasi pembelajaran.

Evaluasi memiliki hubungan dengan subindikator perencanaan, di mana dalam kondisi ketika seorang siswa merencanakan proses belajarnya secara keseluruhan, ia akan memiliki tujuan belajar, sehingga ia juga merencanakan bagaimana ia mengukur apakah ia telah mencapai tujuan belajarnya.

\section{KESIMPULAN}

Berdasarkan rata-rata hasil keseluruhan kesadaran metakognisi siswa masuk dalam kategori baik, yaitu $73,94 \%$. Indikator pengetahuan tentang kognisi siswa dalam kategori baik dengan persentase sebesar $62,99 \%$ dengan subindikator pengetahuan deklaratif $76,25 \%$ dalam kategori baik, pengetahuan prosedural $74,79 \%$ dalam kategori baik, pengetahuan kondisional 37,92\% dalam kategori kurang. Indikator pengetahuan tentang regulasi kognisi dalam kategori baik dengan persentase sebesar 73,51\% dengan subindikator perencanaan $69,64 \%$ dalam kategori baik, strategi manajemen informasi $71,42 \%$ dalam kategori baik, monitoring pemahaman $75,24 \%$ dalam kategori baik, strategi prediksi 79,33\% dalam kategori baik, dan evaluasi 71,94\% dalam kategori baik.

\section{DAFTAR PUSTAKA}

Adhitama, R. S., Kusnadi, \& Supriatno, B. (2014). Kesadaran Metakognitif Siswa dalam Pembelajaran Berbasis Proyek pada Pokok Bahasan Pencemaran Lingkungan.
Asimilasi, 1(1), 2-3.

Alfiyah, N., \& Siswono, T. Y. E. (2014). Identifikasi Kesulitan Metakognisi Siswa dalam Memecahkan Masalah Matematika. Mathedunesa Jurnal Ilmu Pendidikan Matematika, 3(2), 131-138.

Arahma, Y. (2017). Pengaruh Model Pembelajaran Berbasis Masalah (Problem Based Learning) dengan Teknik Mind Mapping terhadap Metakognisi dan Hasil Belajar Biologi. In Skripsi. Jember: Universitas Jember.

Bulu, V. R. (2015). Kesulitan Metakognisi Siswa dalam Memecahkan Masalah Matematika pada Materi Peluang Ditinjau dari Tipe Kepribadian Tipologi Hippocrates-Galenus Kelas XI MIA 1 SMA Negeri 1 Soe di Nusa Tenggara Timur. In Tesis. Surakarta: Universitas Sebelas Maret.

Danial, M. (2010). Kesadaran Metakognisi, Keterampilan Metakognisi dan Penguasaan Konsep Kimia Dasar. Jurnal Ilmu Pendidikan, 17(3), 225-229.

Efendi, N. (2013). Pengaruh Pembelajaran Reciprocal Teaching Dipadukan Think Pair Share terhadap Peningkatan Kemampuan Metakognitif Belajar Biologi Siswa SMA Berkemampuan Akademik Berbeda di Kabupaten Sidoarjo. Jurnal Santiaji Pendidikan (JSP), 3(2), 85-109. Retrieved from

http://ojs.unmas.ac.id/index.php/JSP/article /view/14/0\%0Ahttp://ojs.unmas.ac.id/index .php/JSP/article/download/14/12

Fitria, C., Sujadi, I., \& Subanti, S. (2016). Analisis Kesulitan Metakognisi Siswa dalam Memecahkan Masalah Sistem Pertidaksamaan Linear Dua Variabel Ditinjau dari Tipe Kepribadian Guardian, Artisan, Rational, dan Idealist Kelas X SMKN 1 Jombang. Jurnal Elektronik Pembelajaran Matematika, 4(9), 824-835.

Herlanti, Y. (2015). Kesadaran Metakognitif dan Pengetahuan Metakognitif Peserta Didik Sekolah Menengah Atas dalam Mempersiapkan Ketercapaian Standar Kelulusan Pada Kurikulum 2013. Cakrawala Pendidikan, 34(3), 357-367.

Hidayat, A. F. (2013). Hubungan Regulasi Diri dengan Prestasi Belajar Kalkulus II Ditinjau 
dari Aspek Metakognisi, Motivasi dan Perilaku. Jurnal Elektronik Pendidikan Matematika Tadulako, 01(01), 1-8.

Hill, L. H. (2001). The Brain and Consciousness: Sources of Information for Understanding Adult Learning. Article, 89, 73-82.

Iskandar, S. (2014). Pendekatan Keterampilan Metakognitif dalam Pembelajaran Sains di Kelas. Erudio, 2(2), 13-20.

Lukum, A., Laliyo, L. A. R., \& Sukamto, K. (2015). Metakognisi Mahasiswa dalam Pembelajaran Kesetimbangan Kimia. Jurnal Ilmu Pendidikan, 21(1), 9-18.

Maswandi, F. (2015). Analisis Kemampuan Metakognisi Siswa Berasrama terhadap Materi Ekosistem The Analysis of Metacognitive Ability of Boarding School Students Towards the Subject on Ecosystem. In Seminar Nasional XII Pendidikan Biologi FKIP UNS 2015 (pp. 309-316).

Nurmalasari, L. R., Winarso, W., \& Nurhayati, E. (2015). Pengaruh Kemampuan Metakognisi terhadap Hasil Belajar Matematika di SMP Negeri 2 Lieuwimunding Kabupaten Majalengka. Nusantara of Research, 02(02), 133-147.

Pathuddin. (2009). Pengetahuan Metakognisi dalam Menyelesaikan Masalah Limit. Prosiding Seminar Nasional, 02(1), 50-56.

Prayitno, B. A. (2017). Komparasi Model Pembelajaran Konstruktivis Metakognitif dan Konstruktivis Novick terhadap Berpikir Kritis Ditinjau dari Kemampuan Akademik. Jurnal Penelitian Sosial Keagamaan, 11(1), 25-50.

Schunk, D. H., \& Zimmerman, B. J. (2007). Influencing children's self-Efficacy and self-regulation of reading and writing through modeling. Reading and Writing Quarterly, 23(1), 7-25. https://doi.org/10.1080/1057356060083757 8

Suwarto. (2010). Dimensi Pengetahuan dan Dimensi Proses Kognitif dalam Pendidikan. Widyatama, 19(1), 76-91. 